\title{
Peroxisome Proliferator-Activated Receptor Gamma Exacerbates Concanavalin A-Induced Liver Injury via Suppressing the Translocation of NF- $\kappa$ B into the Nucleus
}

\author{
Yuji Ogawa, ${ }^{1}$ Masato Yoneda, ${ }^{1}$ Wataru Tomeno, ${ }^{1}$ Kento Imajo, ${ }^{1}$ \\ Yoshiyasu Shinohara, ${ }^{1}$ Koji Fujita, ${ }^{1}$ Wataru Shibata, ${ }^{1}$ Hiroyuki Kirikoshi, ${ }^{1}$ \\ Satoru Saito, ${ }^{1}$ Koichiro Wada, ${ }^{2}$ Shin Maeda, ${ }^{1}$ and Atsushi Nakajima ${ }^{1}$ \\ ${ }^{1}$ Department of Gastroenterology, Yokohama City University Graduate School of Medicine, 3-9 Fukuura, Kanazawa-ku, \\ Yokohama 236-0004, Japan \\ ${ }^{2}$ Department of Pharmacology, Osaka University Graduate School of Dentistry, 1-8 Yamadaoka, Suita 565-0871, Japan
}

Correspondence should be addressed to Atsushi Nakajima, nakajima-tky@umin.ac.jp

Received 19 July 2012; Revised 5 November 2012; Accepted 6 November 2012

Academic Editor: Yasuteru Kondo

Copyright ( 2012 Yuji Ogawa et al. This is an open access article distributed under the Creative Commons Attribution License, which permits unrestricted use, distribution, and reproduction in any medium, provided the original work is properly cited.

Peroxisome proliferator-activated receptor- $\gamma(\operatorname{PPAR} \gamma)$ has been reported to reduce inflammation and attenuate fibrosis in the liver. In this study, we investigated the effects of PPAR $\gamma$ on the liver injury induced by $20 \mathrm{mg} / \mathrm{kg}$ Concanavalin A (Con A). The mice were administered one of the three types of PPAR $\gamma$ ligands (pioglitazone, ciglitazone, and troglitazone) for 1 week, and the serum alanine aminotransferase (ALT) levels at $20 \mathrm{~h}$ after Con A injection were significantly elevated in the PPAR $\gamma$ ligand-treated mice. Furthermore, the serum ALT levels after Con A injection in the PPAR $\gamma$ hetero-knock-out mice (PPAR $\gamma^{+/-}$mice) were lower than those in the wild-type mice (WT mice). Terminal deoxynucleotidyl transferase dUTP nick end labeling (TUNEL) revealed extensive liver damage induced by Con A in the pioglitazone-treated mice. Electrophoresis mobility shift assay (EMSA) revealed that activation of translocation of nuclear factor- (NF-) $\kappa \mathrm{B}$, which is a suppressor of apoptosis, in the nucleus of the hepatocytes was suppressed in the pioglitazone-treated mice after Con A injection. In this study, we showed that PPAR $\gamma$ exacerbated Con Ainduced liver injury via suppressing the translocation of NF- $\kappa$ B into the nucleus, thereby inhibiting the suppression of liver cell apoptosis.

\section{Introduction}

PPARs are members of the nuclear receptor superfamily [1]. Three isotypes designated $\operatorname{PPAR} \alpha, \operatorname{PPAR} \beta / \delta$, and $\operatorname{PPAR} \gamma$ have been described in mammals [2]. The PPARs form heterodimers with the retinoid X receptor (RXR), and the PPARRXR heterodimers, when bound to a ligand, change their conformation and bind to the DNA at the PPAR response elements, which results in gene transcription $[3,4]$. PPAR $y$ is expressed in adipose tissue, heart, kidney, skeletal muscle, liver and other organs PPAR $\gamma$ ligands improve insulin resistance and inflammation by increasing serum adiponectin levels [5-7]. Thus, thiazolidinediones (TZDs), which are PPAR $\gamma$ ligands, are widely used in the treatment of type 2 diabetes mellitus (DM).
Liver injury is caused by various factors such as viral infections, autoimmune reactions, and metabolic disorders. Recently, PPAR $y$ agonists have received attention in relation to the treatment of liver diseases. PPAR $\gamma$ has been reported to reduce hepatic inflammation by decreasing the expression of tumor necrosis factor $\alpha$ (TNF- $\alpha$ ) [8], and suppressing the translocation of NF- $\kappa$ B into the nucleus [9]. Furthermore, the PPAR pathway inhibits the fibrogenic actions in hepatic stellate cells and attenuates liver fibrosis in vivo $[10,11]$. $\operatorname{PPAR} \gamma$ agonists have been reported to be useful in mice and humans with NAFLD [12-14], as PPAR $\gamma$ promotes adipocyte differentiation [15], increases triglyceride storage in adipocyte, and reduces delivery of fatty acids to the liver [9]. However the effect on other liver diseases has not yet been investigated. 


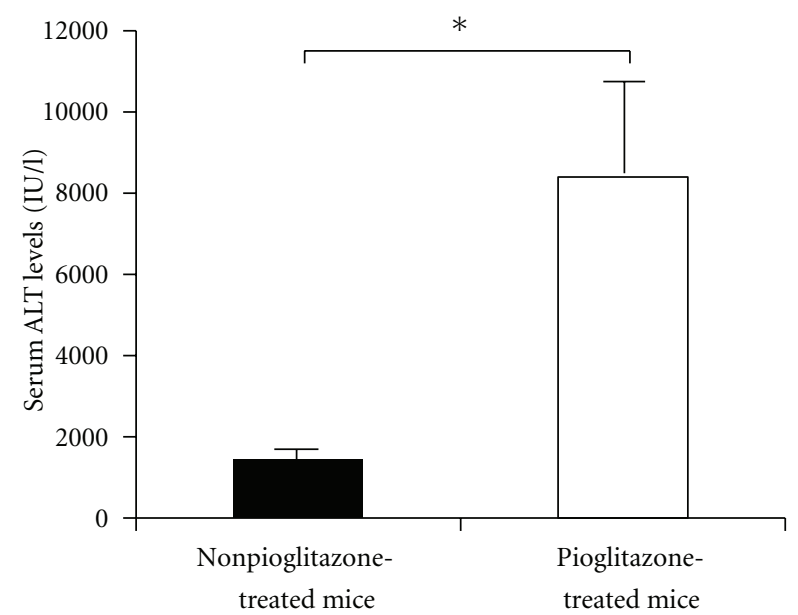

(a)

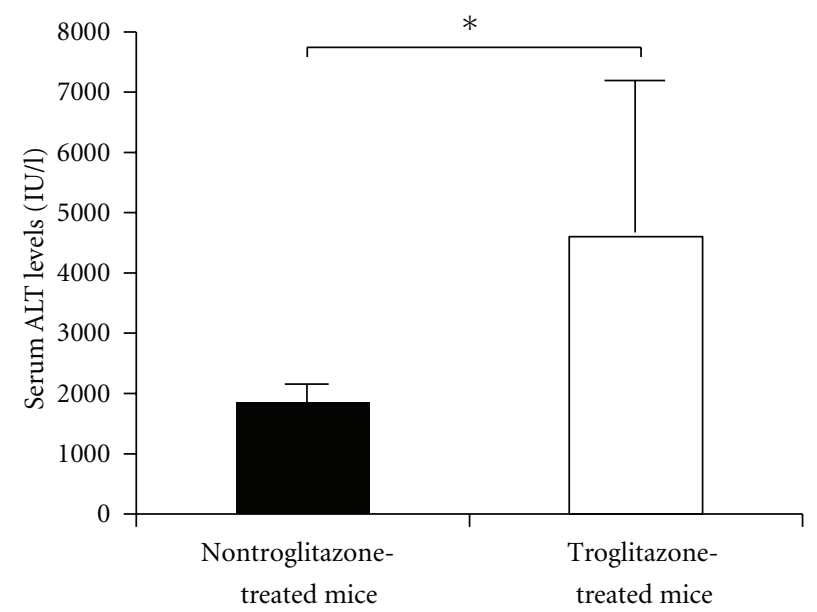

(c)

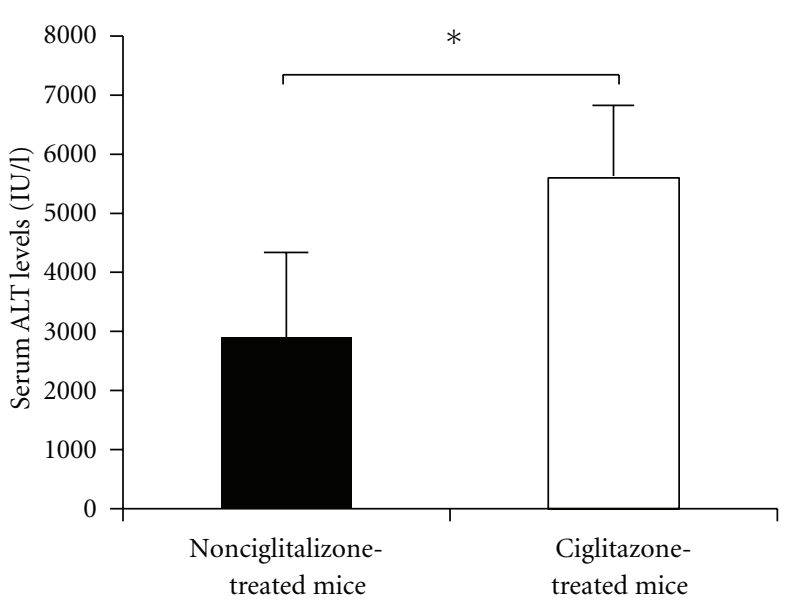

(b)

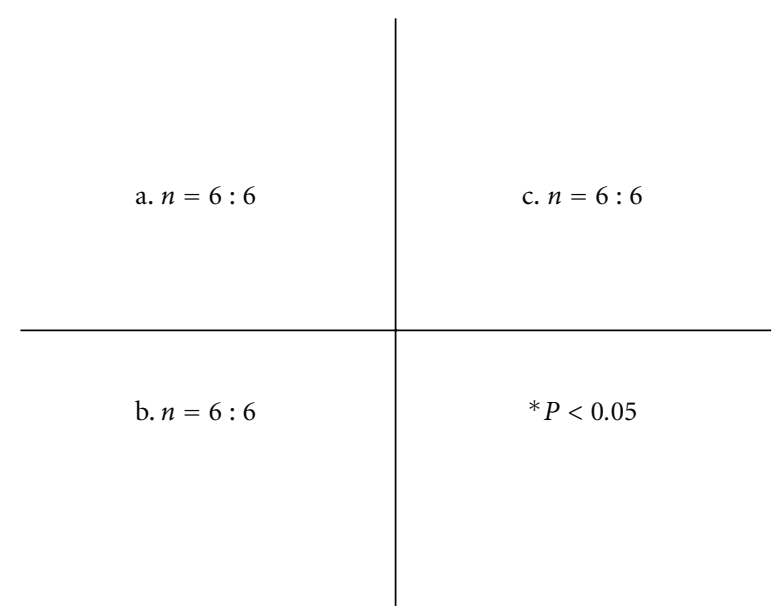

(d)

FIgURE 1: At $20 \mathrm{~h}$ after Con A injection, the serum ALT levels in the mice treated with one of the three types of PPAR $\gamma$ ligands (pioglitazone (a), troglitazone (b), ciglitazone (c)) were significantly higher as compared with those in the non-PPAR $\gamma$-treated mice $\left({ }^{*} P<0.05\right)$.

In this study, PPAR $y$ ligands and PPAR $\gamma^{+/-}$mice were used to confirm the effects of PPAR $y$ on the liver injury induced by Con A. Con A induces serious hepatitis in mice by activating $\mathrm{T}$ cells and triggering apoptosis $[16,17]$.

\section{Materials and Methods}

2.1. Animal Experiments. Eight-week-old male WT BALB/c mice and eight-week-old male PPAR $\gamma^{+/-}$mice on a BALB/c background were purchased from CLEA Japan, Inc. and Jackson Laboratory (Bar Harbor, ME, USA), respectively. All the mice were maintained in filter-topped cages on autoclaved normal chow diet containing $22 \%$ protein, $6 \%$ fat, and $47 \%$ carbohydrate. In the Con A-induced hepatitis model, Con A (Sigma Aldrich, St. Louis, MO, USA; $20 \mathrm{mg} / \mathrm{kg}$ ) was injected intravenously (i.v.) into mice. First, WT mice ( $n=6$ mice) were fed either a control chow or chow supplemented with one of the two types of PPAR $y$ ligands (ciglitazone $(100 \mathrm{mg} / \mathrm{kg})$ and troglitazone $(150 \mathrm{mg} / \mathrm{kg}))$ ad libitum for 1 week and sacrificed at $20 \mathrm{~h}$ after the Con A injection.

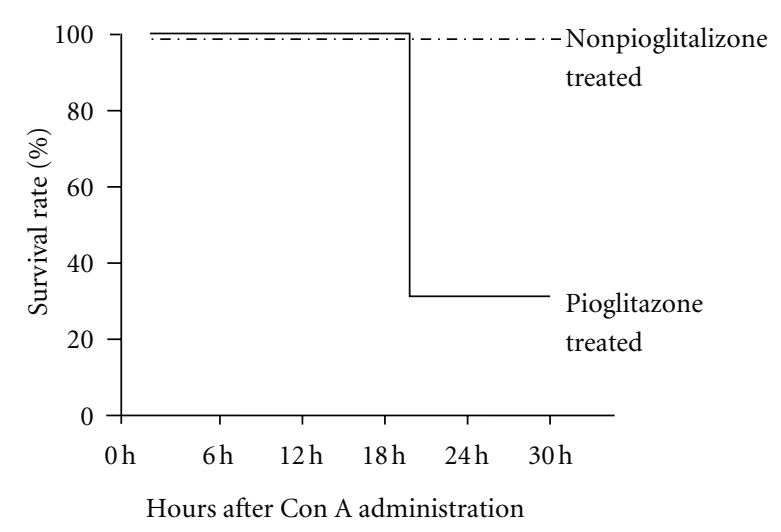

Figure 2: At $20 \mathrm{~h}$ after Con A injection, there were no cases of fatality in the nonpioglitazone-treated group of mice, whereas the fatality rate was $70 \%$ in the pioglitazone-treated mice.

These doses and duration of treatment with the PPAR $y$ agonists were selected based on the efficacy demonstrated in 


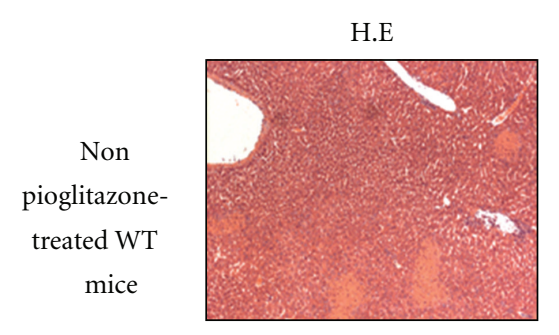

(a) $(\times 40)$

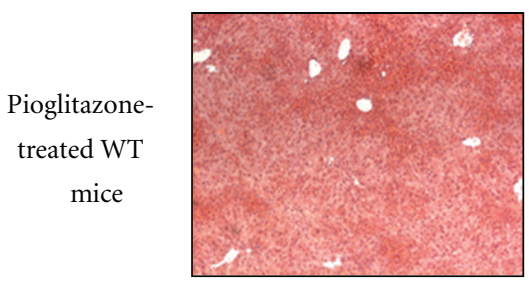

(c) $(\times 40)$

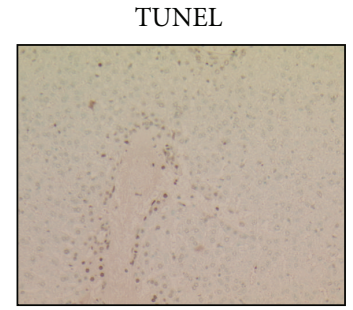

(b) $(\times 40)$

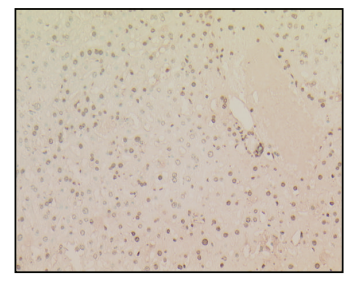

(d) $(\times 40)$

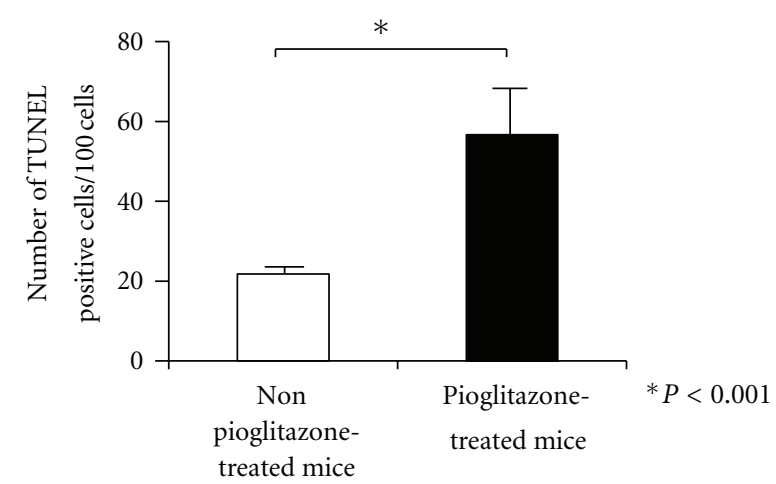

(e)

FIgure 3: Histopathological examination of liver sections stained with H-E at 20 h after Con A injection revealed more extensive liver necrosis in the pioglitazone-treated mice (c) in comparison with that in the nonpioglitazone-treated mice (a). TUNEL assay at $20 \mathrm{~h}$ after Con A injection revealed more extensive liver apoptosis in the pioglitazone-treated mice (d) as compared with that in the nonpioglitazonetreated mice (b). The number of TUNEL-positive cells/100 cells was three-times higher in the livers of the pioglitazone-treated mice as compared with that in the livers of the nonpioglitazone-treated mice $(56 \pm 8.01$ versus $21 \pm 1.83, P<0.001)$.

pilot experiments (data not shown). Subsequently, PPAR $\gamma^{+/-}$ mice were treated with either control chow or pioglitazonesupplemented chow and sacrificed at $20 \mathrm{~h}$ after the Con A injection. Finally, to investigate the effect of PPAR $y$ on the activation of NF- $\kappa \mathrm{B}$ induced by Con $\mathrm{A}$, control or pioglitazone-supplemented chow was administered to the WT mice and sacrificed at various time points $(0.5 \mathrm{~h}, 1 \mathrm{~h}$, $3 \mathrm{~h}, 6 \mathrm{~h}$, and $8 \mathrm{~h}$ ) after the Con A injection, to obtain nuclear protein. The animal protocols were approved by the Yokohama City University Medical School Guidelines for the Care and Use of Laboratory Animals.

2.2. Biochemistry. Serum alanine aminotransferase (ALT) levels were measured by a local laboratory for clinical examinations (SRL Co, Ltd., Tokyo, Japan).

2.3. Liver Histology. Liver specimens were fixed overnight in buffered formaldehyde (10\%) and embedded in paraffin.
Paraffin sections were prepared at $5 \mu \mathrm{m}$ thickness and stained with hematoxylin and eosin (H-E).

2.4. Assay for Apoptosis. The apoptotic tumor cells were stained using a TUNEL staining kit, according to the manufacturer's instructions (Wako Pure Chemical, Osaka, Japan). In brief, paraffin sections were digested with $20 \mu \mathrm{g} / \mathrm{mL}$ of proteinase K (Takara, Shiga, Japan) for $15 \mathrm{~min}$ at room temperature and reacted with terminal deoxynucleotidyl transferase enzyme for $60 \mathrm{~min}$ at $37^{\circ} \mathrm{C}$. The sections were then incubated with antidigoxigenin conjugate at room temperature for $30 \mathrm{~min}$, followed by incubation with diaminobenzidine solution.

2.5. Electrophoretic Mobility Shift Assay (EMSA). NF- $\kappa$ B binding was determined by EMSA. We collected liver tissue specimens at various time points $(0.5,1,3,6$, and $8 \mathrm{~h})$ after the Con A injection. Nuclear protein extracts $(10 \mu \mathrm{g})$ were prepared using Nuclear Extraction kit (BizScience, Osaka, 
Japan), according to the manufacturer's instructions. The probe oligonucleotide was $22 \mathrm{bp}$, double-stranded (5'GCCTGGGAAAGTCCCCTCAACT-3' $)$ and endlabeled with biotin (Sigma Chemical, St. Louis, MO). DNA-protein complexes were resolved at $80 \mathrm{~V}$ for $1 \mathrm{~h}$ in a taurine-buffered, native $6 \%$ polyacrylamide gel ( $4 \%$ for supershift) and blotted onto a positively charged nylon membrane (Sigma Chemical, St. Louis, MO). Transferred DNA was immediately crosslinked to the membrane on an ultraviolet transilluminator equipped with $312 \mathrm{~nm}$ bulbs and detected using horseradish peroxidase-conjugated streptavidin (Light-Shift Chemiluminescent EMSA kit), according to the manufacturer's instructions.

2.6. Statistical Analysis. Data are presented as means \pm SD. Differences between the two groups were assessed using the unpaired two-tailed Student's $t$-test; $P$ values of $<0.05$ were considered to denote significance. All statistical analyses were performed using Microsoft Excel and the SPSS 16.0 statistical package (SPSS, Chicago, IL)

\section{Results and Discussion}

To assess the degree of liver injury, we analyzed the time course of changes of the serum ALT levels after the Con A injection. Unexpectedly, the serum ALT levels in the pioglitazone- $(30 \mathrm{mg} / \mathrm{kg})$ treated mice were significantly higher in comparison with that in the nonpioglitazone-treated mice at $20 \mathrm{~h}$ after Con A injection (Figure 1(a)). The survival rate of the nonpioglitazone-treated mice was $100 \%$, while that of the pioglitazone- $(30 \mathrm{mg} / \mathrm{kg})$ treated mice was $30 \%$ at $20 \mathrm{~h}$ after Con A injection (Figure 2). Subsequently, we conducted a histological examination to assess the degree of Con Ainduced liver injury at $20 \mathrm{~h}$ after Con A injection in the mice treated and not treated with $30 \mathrm{mg} / \mathrm{kg}$ of pioglitazone. Histopathological examination of tissue sections stained with $\mathrm{H}-\mathrm{E}$ revealed that the liver damage was more extensive in the pioglitazone-treated mice as compared with that in the nonpioglitazone-treated mice (Figures 3(a) and 3(c)). To determine the presence and extent of apoptotic cells, we performed TUNEL assay. More TUNEL-positive hepatocytes could be detected in the liver sections of the pioglitazonetreated mice than in those of the control mice (Figures $3(\mathrm{~b})$ and $3(\mathrm{~d}))$. The number of TUNEL positive cells/100 cells in the livers of the pioglitazone-treated mice was threetimes higher as compared with that in the livers of the nonpioglitazone-treated mice $(56.2 \pm 8.0$ versus $21.0 \pm 1.8$, $P<0.001)$. From these results, we hypothesized that PPAR $\gamma$ might actually exacerbate Con A-induced liver injury by intensifying hepatocyte apoptosis. Then, we used two other $\operatorname{PPAR} \gamma$ ligands (ciglitazone and troglitazone) to confirm the effect of PPAR $\gamma$. All of the three PPAR $\gamma$ ligands produced a significant increase of the serum ALT levels in the treated mice as compared with the levels in the untreated mice (Figures $1(\mathrm{a}), 1(\mathrm{~b})$, and $1(\mathrm{c}))$. This result indicates that PPAR $\gamma$ ligands exacerbate Con A-induced liver injury regardless of the kinds.

To evaluate the effect of PPAR $\gamma$ on liver injury, we used PPAR $\gamma^{+/-}$mice. The reason for using the heterologous

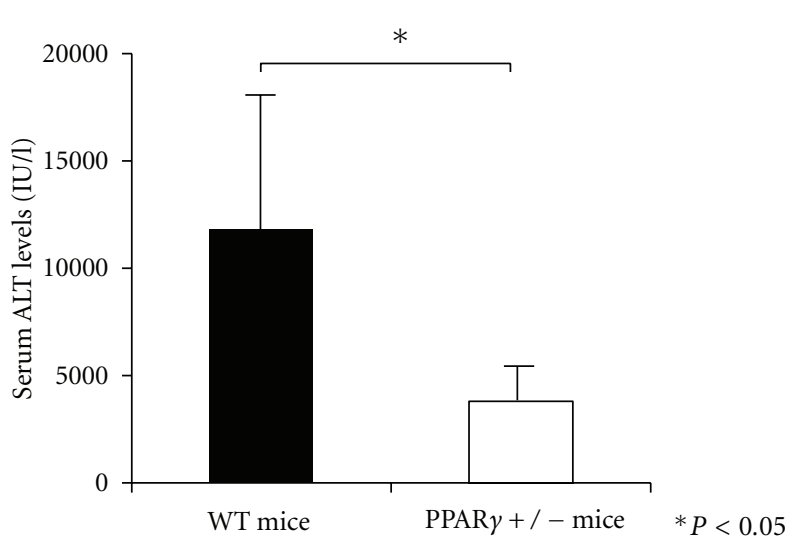

Figure 4: At $20 \mathrm{~h}$ after Con A injection, the serum ALT levels in the WT mice were significantly higher than those in the PPAR $\gamma^{+/-}$mice.

PPAR $\gamma^{+/-}$mice was that double knock-out of this gene results in embryonic lethality. Con A-induced liver injury was less extensive in the PPAR $\gamma^{+/-}$mice as compared with that in the WT mice (Figure 4). This result suggests the possible involvement of the endogenous PPAR $\gamma$-mediated pathway in the exacerbation of Con A-induced liver injury.

To confirm the apoptosis in the pioglitazone-treated and nonpioglitazone-treated mice after Con A-injection, we analyzed the expression of NF- $\kappa \mathrm{B}$, which is a known suppressor of apoptosis. To determine the quantity of activated NF- $\kappa \mathrm{B}$, we performed EMSA. Activation of NF- $\kappa \mathrm{B}$ in the hepatocyte nuclei after Con A-injection was suppressed in the livers of the pioglitazone-treated mice as compared with that in the livers of the nonpioglitazone-treated mice (Figure 5). This result suggests that PPAR $\gamma$ suppresses the translocation of $\mathrm{NF}-\kappa \mathrm{B}$ into the nucleus, thereby inhibiting the suppression of liver cell apoptosis. Maeda et al. reported that hepatocytespecific IKK $\beta$ knockout mice exhibit little NF- $\kappa$ B activity and are highly susceptible to liver apoptosis of Con A-induced liver injury [18].

From this study, suppression of PPAR $\gamma$, such as using $\operatorname{PPAR} \gamma$ antagonists may potentially reduce the extent of liver injury.

\section{Conclusion}

In this study, we showed that PPAR $\gamma$ ligands exacerbate Con $\mathrm{A}$-induced liver injury via suppressing the translocation of $\mathrm{NF}-\kappa \mathrm{B}$ into the nucleus. Con A-induced liver injury in PPAR $\gamma$-treated mice represents an intensified apoptosis. PPAR $\gamma$ antagonists may be considered as novel candidates for the therapy of liver injury in an intensifying apoptosis model.

\section{Abbreviations}

PPAR $\gamma:$ Peroxisome proliferator-activated receptor- $\gamma$

NAFLD: Nonalcoholic fatty liver disease

Con A: Concanavalin A

ALT: $\quad$ Alanine aminotransferase

WT mice: Wild-type mice 


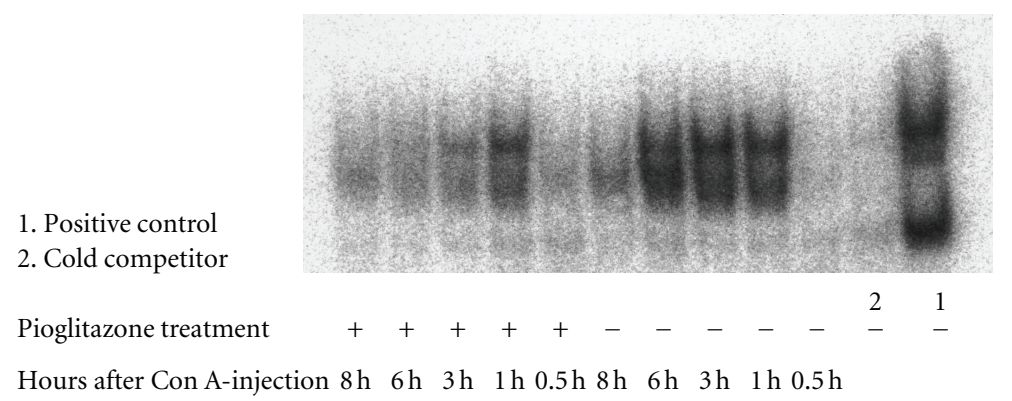

Figure 5: NF- $\kappa \mathrm{B}$ binding was determined by EMSA. We collected liver tissue specimens at various time points $(0.5,1,3,6$, and $8 \mathrm{~h})$ after Con $\mathrm{A}$ injection. At $1 \mathrm{~h}$ after the Con $\mathrm{A}$ injection, NF- $\kappa \mathrm{B}$ was activated in the nonpioglitazone-treated mice, whereas the NF- $\kappa \mathrm{B}$ activation was suppressed in the pioglitazone-treated mice.

\section{TUNEL: Terminal deoxinucleotidyl transferase dUTP nick end labeling \\ EMSA: Electrophoresis mobility shift assay \\ NF: $\quad$ Nuclear factor \\ RXR: Retinoid X receptor \\ TZDs: Thiazolidinediones \\ DM: Diabetes mellitus \\ TNF- $\alpha$ : Tumor necrosis factor $\alpha$ \\ H-E: Hematoxylin and eosin.}

\section{Acknowledgment}

The authors thank Machiko Hiraga for her technical assistance.

\section{References}

[1] B. Desvergne and W. Wahli, "Peroxisome proliferator-activated receptors: nuclear control of metabolism," Endocrine Reviews, vol. 20, no. 5, pp. 649-688, 1999.

[2] "A unified nomenclature system for the nuclear receptor superfamily," Cell, vol. 97, no. 2, pp. 161-163, 1999.

[3] O. Bardot, T. C. Aldridge, N. Latruffe, and S. Green, "PPARRXR heterodimer activates a peroxisome proliferator response element upstream of the bifunctional enzyme gene," Biochemical and Biophysical Research Communications, vol. 192, no. 1, pp. 37-45, 1993.

[4] K. L. Gearing, M. Gottlicher, M. Teboul, E. Widmark, and J. A. Gustafsson, "Interaction of the peroxisome-proliferatoractivated receptor and retinoid X receptor," Proceedings of the National Academy of Sciences of the United States of America, vol. 90, no. 4, pp. 1440-1444, 1993.

[5] C. H. Lee, P. Olson, A. Hevener et al., "PPAR $\delta$ regulates glucose metabolism and insulin sensitivity," Proceedings of the National Academy of Sciences of the United States of America, vol. 103, no. 9, pp. 3444-3449, 2006.

[6] I. F. Charo, "Macrophage polarization and insulin resistance: PPAR $\gamma$ in control," Cell Metabolism, vol. 6, no. 2, pp. 96-98, 2007.

[7] N. Maeda, M. Takahashi, T. Funahashi et al., "PPAR $\gamma$ ligands increase expression and plasma concentrations of adiponectin, an adipose-derived protein," Diabetes, vol. 50, no. 9, pp. 20942099, 2001.

[8] C. Hofmann, K. Lorenz, S. S. Braithwaite et al., "Altered gene expression for tumor necrosis factor- $\alpha$ and its receptors during drug and dietary modulation of insulin resistance," Endocrinology, vol. 134, no. 1, pp. 264-270, 1994.

[9] R. B. Clark, "The role of PPARs in inflammation and immunity," Journal of Leukocyte Biology, vol. 71, no. 3, pp. 388-400, 2002.

[10] F. Marra, E. Efsen, R. G. Romanelli et al., "Ligands of peroxisome proliferator-activated receptor $\gamma$ modulate profibrogenic and proinflammatory actions in hepatic stellate cells," Gastroenterology, vol. 119, no. 2, pp. 466-478, 2000.

[11] A. Galli, D. W. Crabb, E. Ceni et al., "Antidiabetic thiazolidinediones inhibit collagen synthesis and hepatic stellate cell activation in vivo and in vitro," Gastroenterology, vol. 122, no. 7, pp. 1924-1940, 2002.

[12] K. Matsusue, M. Haluzik, G. Lambert et al., "Liver-specific disruption of PPAR $\gamma$ in leptin-deficient mice improves fatty liver but aggravates diabetic phenotypes," Journal of Clinical Investigation, vol. 111, no. 5, pp. 737-747, 2003.

[13] O. Gavrilova, M. Haluzik, K. Matsusue et al., "Liver peroxisome proliferator-activated receptor $\gamma$ contributes to hepatic steatosis, triglyceride clearance, and regulation of body fat mass," The Journal of Biological Chemistry, vol. 278, no. 36, pp. 34268-34276, 2003.

[14] R. Belfort, S. A. Harrison, K. Brown et al., "A placebo controlled trial of pioglitazone in subjects with nonalcoholic steatohepatitis," The New England Journal of Medicine, vol. 355, no. 22, pp. 2297-2307, 2006.

[15] P. Tontonoz, E. Hu, R. A. Graves, A. I. Budavari, and B. M. Spiegelman, "mPPAR $\gamma 2$ : Tissue-specific regulator of an adipocyte enhancer," Genes and Development, vol. 8, no. 10, pp. 1224-1234, 1994.

[16] G. Tiegs, J. Hentschel, and A. Wendel, "A T cell-dependent experimental liver injury in mice inducible by concanavalin A," Journal of Clinical Investigation, vol. 90, no. 1, pp. 196-203, 1992.

[17] W. Guo, W. Liu, S. Hong et al., "Mitochondrial-dependent apoptosis of con a-activated T lymphocytes induced by Asiatic Acid for preventing murine fulminant hepatitis," PLoS One, vol. 7, no. 9, Article ID e46018, 2012.

[18] S. Maeda, L. Chang, Z. W. Li, J. L. Luo, H. Leffert, and M. Karin, "IKK $\beta$ is required for prevention of apoptosis mediated by cell-bound but not by circulating TNF $\alpha$," Immunity, vol. 19, no. 5, pp. 725-737, 2003. 


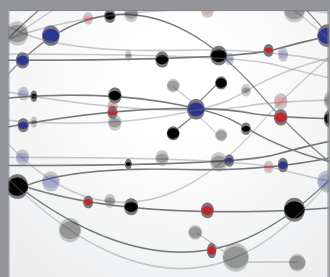

The Scientific World Journal
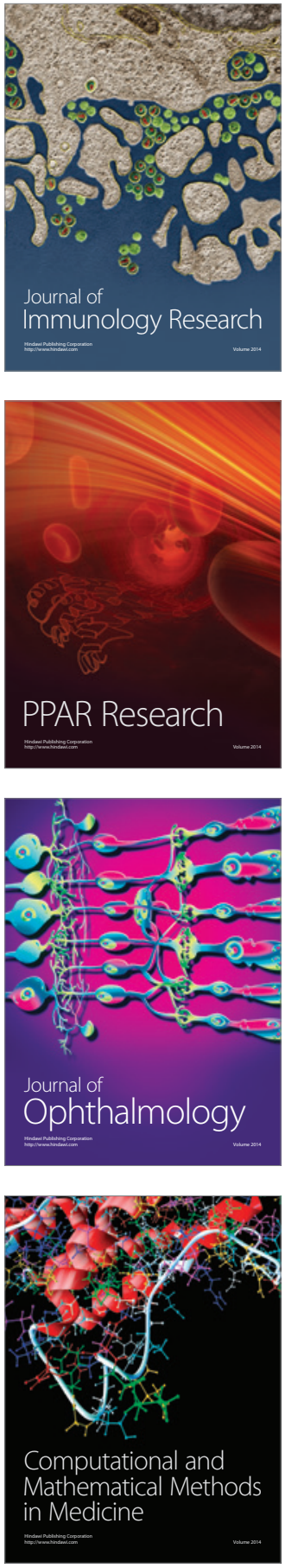

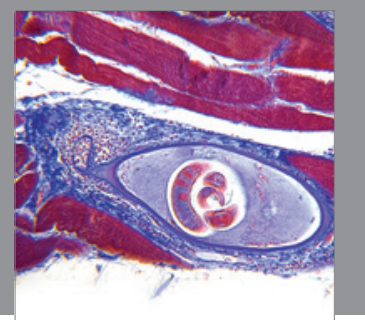

Gastroenterology

Research and Practice
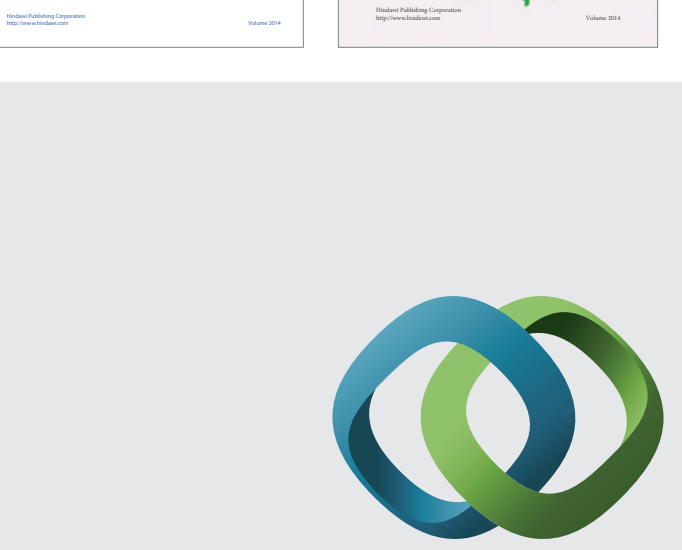

\section{Hindawi}

Submit your manuscripts at

http://www.hindawi.com
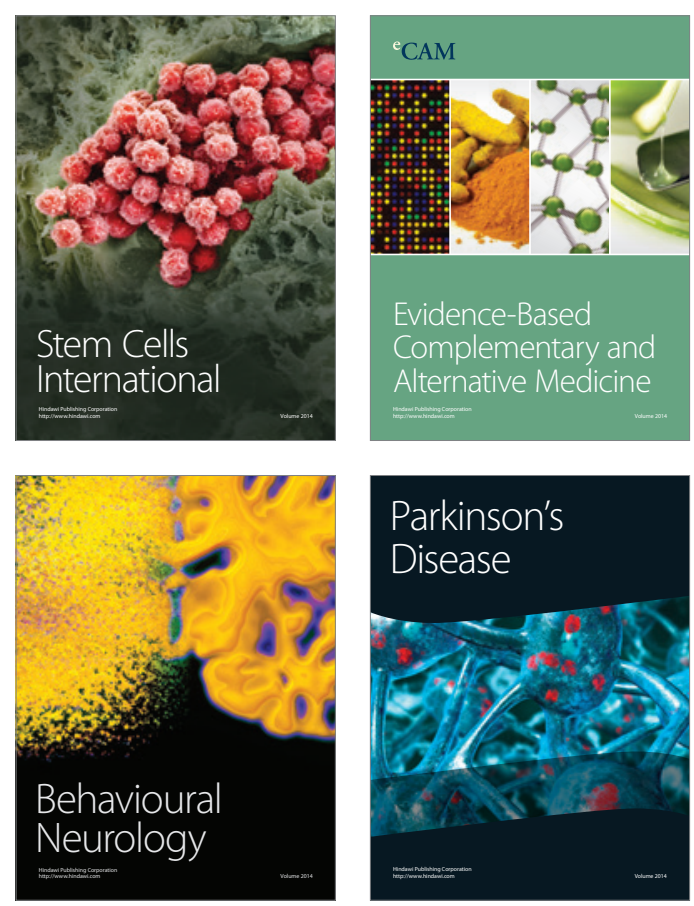

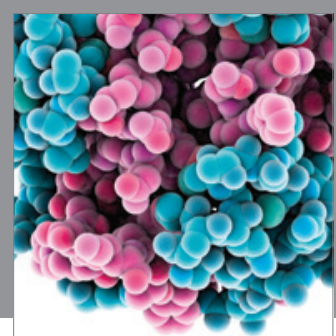

Journal of
Diabetes Research

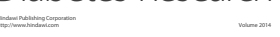

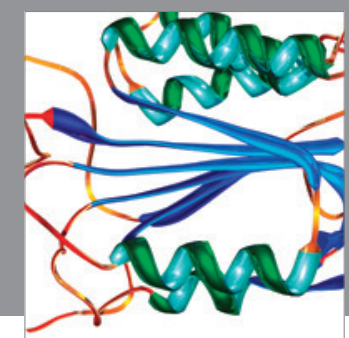

Disease Markers
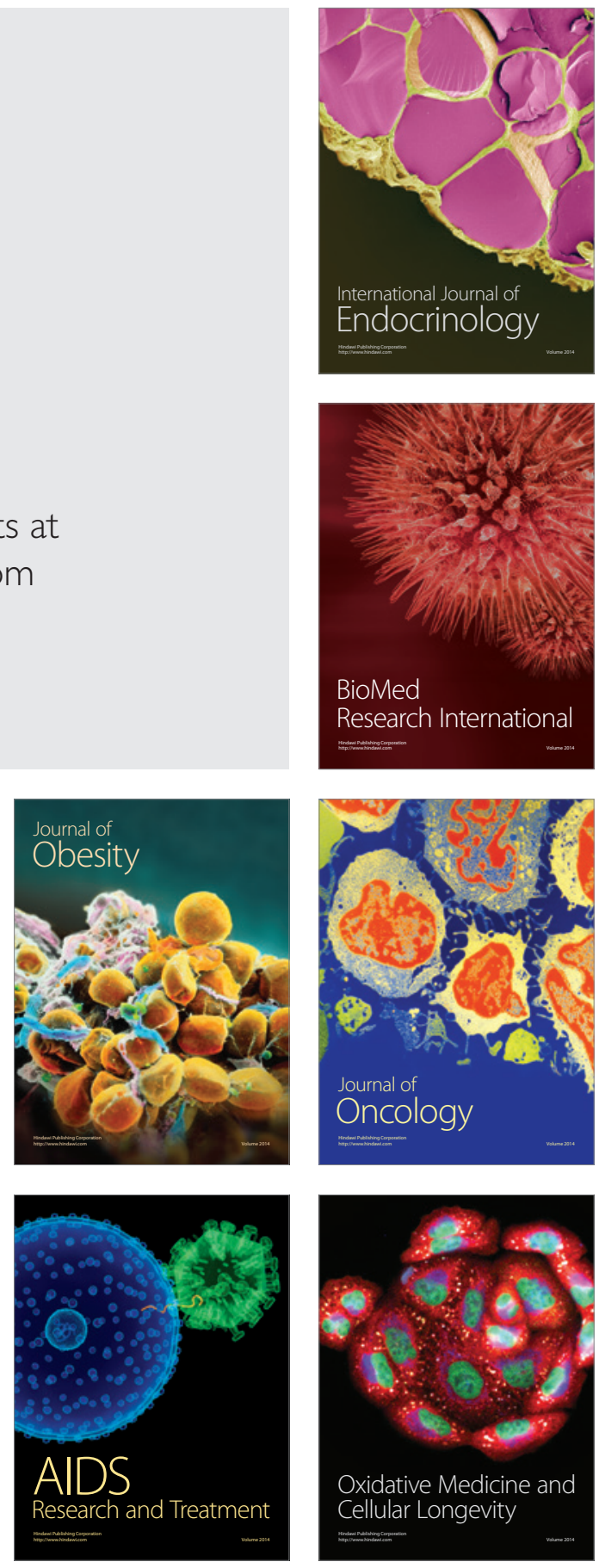